\title{
Poplar Seeds Capabilities to Germinate on a Metal(Loid)S Contaminated Mining Technosol Differently Amended
}

\author{
Florie Miard ${ }^{1}$, Romain Nandillon ${ }^{1,2,3}$, Manhattan Lebrun ${ }^{1,4}$, Marie Gaillard², Stéphane Sabatier², \\ Sylvain Bourgerie ${ }^{1}$, Domenico Morabito ${ }^{1}$ \\ ${ }^{1}$ Université d'Orléans, LBLGC INRA USC1328 \\ rue de Chartres, BP 6759, 45067 Orléans Cedex 2, France \\ manhattan.lebrun@etu.univ-orleans.fr; florie.miard@univ-orleans.fr; domenico.morabito@univ-orleans.fr; \\ sylvain.bourgerie@univ-orleans.fr \\ ${ }^{2}$ IDDEA, Environmental consulting engineering \\ 45160 Olivet, France \\ romain.nandillon@iddea-ingenierie.fr; marie.gaillard@iddea-ingenierie.fr; stephane.sabatier@iddea-ingenierie.fr \\ ${ }^{3}$ BRGM, ISTO, UMR 7327, BP 36009 \\ 45060 Orléans, France \\ ${ }^{4}$ Università degli Studi del Molise, Dipartimento di Bioscienze e Territorio \\ 86090, Pesche, Italy
}

\section{Extended Abstract}

Mining activities are one of the main sources of environment contamination through metal(loid)s released due to soil erosion [1]. High concentrations of metal(loid)s in soils and consequently into soil groundwater could have negative effects on terrestrial ecosystems and could pose potential health risks. Consequently depollution techniques such as physical or chemical methods have been developed to reduce the impact of such pollution. However such techniques are expensive and disturb the normal biological soil activities. Phytoremediation technics, which use specific plants and the associated microorganisms to control soil metal(loid)s availability in situ, are low cost alternative technologies [2]. However few physicochemical characteristics of tailings such as low $\mathrm{pH}$, lack of nutrients and metal(loid)s toxicity could limit this strategy [3].

To overcome these limitations and to allow an efficient plant recolonization through seeds germination, amendments must be added to the technosol [4]. Among the amendments used, biochar has attracted attention in recent years because of its beneficial effects (i) on soil fertility (ii) on cationic metal(loid)s sorption. However, soil biochar application does not contribute efficiently to plant growth and sometimes soil must be complemented with other amendments [5] such as compost, manure or garden soil.

Therefore, the combination of amendments seems a better option to improve the agronomic capacity of a technosol while maintaining the capacity of the biochar to immobilize metal(loid)s pollutants.

The aims of our study were (i) to evaluate in mesocosm the germination capacity of black poplar seeds (Populus nigra) on a mining technosol, amended or not and (ii) to determine the best amendments combination.

Eight different conditions were studied: $(\mathrm{P})$ mining technosol; $(\mathrm{P}+\mathrm{B})$ mining technosol $+2 \%$ hardwoodderived biochar; $(\mathrm{P}+\mathrm{G})$ mining technosol $+10 \%$ garden soil; $(\mathrm{P}+\mathrm{C})$ mining technosol $+10 \%$ compost and combinations of different amendments: $(\mathrm{P}+\mathrm{G}+\mathrm{B})$ and $(\mathrm{P}+\mathrm{C}+\mathrm{B})$. The physicochemical properties and the metal(loid)s concentrations of the soil pore water were measured. Germination rate, plant growth and metal(loid)s concentrations into plant organs were determined. An optimal amendment mixture was proposed to allow an efficient seed germination. 


\section{References}

[1] Razo, et al., "Arsenic and heavy metal pollution of soil, water and sediments in a semi-arid climate mining area in mexico," Water, Air, and Soil Pollution, vol. 152, pp. 129-152, 2004.

[2] T. Vamerali, et al., "Phytoremediation trials on metal- and arsenic-contaminated pyrite wastes (Torviscosa, Italy)," Environ. Pollut., vol. 157, pp. 887-89, 2009.

[3] M. H. Wong, "Ecological restoration of mine degraded soils, with emphasis on metal contaminated soils," Chemosphere, vol. 50, pp. 775-780, 2003.

[4] P. Alvarenga, et al., "Organic residues as immobilizing agents in aided phytostabilization: (II) effects on soil biochemical and ecotoxicological characteristics," Chemosphere, vol. 74, pp. 1301-1308, 2009.

[5] L. Beesley, et al., "A review of biochars potential role in the remediation, revegetation and restoration of contaminated soils," Environmental Pollution, vol. 159, pp. 3269-3282, 2011. 